\title{
HUBUNGAN PENGETAHUAN DAN DUKUNGAN SUAMI DENGAN PERILAKU PEMERIKSAAN INSPEKSI VISUAL ASAM ASETAT (IVA) PADA WANITA USIA SUBUR SEPULAU LOMBOK NUSA TENGGARA BARAT TAHUN 2020
}

\author{
Humaediah Lestari ${ }^{1}$, Kristiani Murti Kisid ${ }^{2}$, Sri Hardiani ${ }^{3}$ \\ ${ }^{1,2,3)}$ Sekolah Tinggi Ilmu Kesehatan (STIKES) Mataram, \\ Jl. Swakarsa III No.10 Kekalik Mataram NTB \\ lestarihumaediaha@yahoo.com
}

\begin{abstract}
ABSTRAK
Diketahui dari data Profil Kesehatan Indonesia tahun 2018, Nusa Tenggara Barat (NTB) termasuk 9 provinsi tertinggi kasus IVA positif. Selain itu, dari total 722.347 sasaran baru $95.651(13,24 \%)$ WUS yang diperiksa menggunakan IVA. Kanker serviks merupakan pembunuh nomor 2 terbanyak wanita di Indonesia. Kanker serviks merupakan kanker leher rahim yang disebabkan oleh Human Pappiloma Virus (HPV). Menurut Kementerian Kesehatan Indonesia (2019) rata-rata kematian akibat kanker serviks sebanyak 13,9 per 100.000 penduduk. Kanker serviks dapat dicegah dengan vaksinasi dan deteksi dini menggunakan pap smear dan Inspeksi Visual Asam Asetat (IVA). Tujuan penelitian ini adalah untuk mengetahui hubungan antara pengetahuan, motivasi dan dukungan suami dengan pemeriksaan IVA pada WUS.

Penelitian ini menggunakan kuesioner online yang dibuat dengan aplikasi google form yang disebar secara online. Populasi penelitian ini adalah WUS usia 15-49 tahun yang telah kawin dan berdomisili di Pulau Lombok. Sampel diambil menggunakan metode non probability sampling dengan accidental sampling berjumlah 37 WUS. Rancangan studi yang dgunakan adalah cross sectional. Uji analisa data menggunakan uji deskriptif Chi square dengan tingkat kesalahan 5\%.

Dari penelitian yang dilakukan sebagian besar WUS tidak melakukan pemeriksaan IVA $(91,9 \%)$ dan tidak ada hubungan yang signifikan antara pengetahuan $(0,789)$ motivasi $(1,00)$ dan dukungan suami $(0,548)$ dengan perilaku pemeriksaan IVA. Kesimpulan penelitian ini adalah sebagian besar WUS tidak melakukan pemeriksaan IVA $(91,9 \%)$ dan tidak ada hubungan antara pengetahuan $(0,789)$ dan dukungan suami $(0,548)$ dengan perilaku pemeriksaan IVA.

Mengingat masih banyaknya WUS yang belum pernah melakukan skrining kanker serviks dengan metode IVA maka diharapkan adanya intervensi dari pihak tenaga kesehatan .untuk lebih menggalakkan promosi tentang pemeriksaan IVA dan semakin menggalakkan pemeriksaan IVA gratis terutama di pedesaan tidak hanya di perkotaan.
\end{abstract}

Kata Kunci: Pemeriksaan IVA, pengetahuan, dukungan suami, WUS

\section{PENDAHULUAN}

Kanker merupakan penyakit yang merenggut jutaan nyawa orang di dunia, bahkan WHO memperkirakan ada 14 juta orang yang telah mengidap kanker dan angkanya akan mencapai 19 juta di tahun 2025. Di Indonesia angka prevalensi kanker mencapai $1,4 / 1000$ penduduk (Sudrajat, 2017). Berdasarkan data dari Globalcan 2018 kanker serviks merupakan kanker terbanyak yang 
menyerang wanita di Indonesia setelah kanker payudara dengan angka kejadian kanker serviks sebesar 23,4/100 ribu penduduk (Kemenkes RI, 2019). Hal ini menjadikan Indonesia menurut WHO sebagai Negara dengan jumlah penderita kanker serviks tertinggi, sehingga upaya pencegahan kanker serviks sangat diperlukan.

Skrining kanker leher rahim dengan metode Inspeksi Visual dengan Asam Asetat (IVA) pada 10 kabupaten/kota yang ada di Provinsi NTB berhasil memeriksa 95.651 orang dari total 722.347 orang WUS usia 30-50 tahun. Hasil yang didapatkan adalah IVA positif sebanyak 1.069 kasus dan menduduki peringkat kesembilan Provinsi dengan kasus IVA positif terbanyak di Indonesia (Profil Kesehatan Indonesia, 2018). Artinya, baru sebagian kecil $(13,24 \%)$ WUS yang di skrining menggunakan IVA sehingga akan memungkin terjadinya banyak kasus kanker serviks yang terlambat ditangan di masa mendatang.

Ada berbagai faktor yang dapat menyebabkan WUS berperilaku tidak melakukan pemeriksaan IVA, pertama adalah factor predisposisi seperti tingkat pengetahuan yang kurang dimana pengetahuan akan menjadi dasar dari perilaku, seseorang, termasuk kepercayaan, nilai, sikap dan keadaan demografi. Selanjutnya adalah factor pemungkin seperti keterjangkauan biaya yang akan mempengaruhi minat periksa, termasuk keterampilan, fasilitas, sarana dan prasaranan yang akan memfasilitasi minat WUS. Terakhir adalah factor penguat seperti dukungan dari keluarga dalam hal ini suami akan sangat berpengaruh karena masyarakat Indonesia masih banyak yang menganut budaya patrilineal, termasuk teman dan petugas kesehatan yang diharapkan tetap mendampingi/mendorong perilaku WUS untuk tetap melakukan periksa IVA (Agustini, 2019).
Penelitian yang dilakukan oleh Meliasari (2014) diketahui bahwa terdapat hubungan antara dukungan suami $(p=0,00)$ dan pengetahuan $(p=0,00)$ dengan perilaku periksa IVA PUS. Penelitian lainnya oleh Pakkan (2017) diperoleh hasil ada pengaruh antara pengetahuan $(p=0,01)$ dengan motivasi ibu melakukan pemeriksaan IVA. Sedangkan penelitian yang dilakukan oleh Wildayanti (2017) menunjukkan bahwa terdapat hubungan antara dukungan suami (0.031) dengan keikutsertaan pemeriksaan IVA pada PUS.

Sebagian besar wanita usia produktif Indonesia masih kurang memahami informasi mengenai kanker serviks, hal ini sangat disayangkan mengingat kanker serviks merupakan kanker yang bisa dicegah sejak dini. Tingginya angka kematian kejadian kanker serviks menjadikan sangat perlunya upaya pencegahan dan deteksi dini karena akan sangat berdampak bagi WUS, keluarga hingga pemerintah. Pemeriksaan IVA merupakan salah satu upaya skrining kanker serviks termurah selain Pap smear. Pemeriksaan IVA dapat dilakukan pada tingkat pelayanan primer dengan sarana dan prasarana terbatas.

Oleh karenanya, peneliti tertarik melakukan penelitian ini dengan tujuan untuk mengetahui hubungan pengetahuan dan dukungan suami dengan perilaku periksa IVA WUS di Pulau Lombok.

\section{BAHAN DAN METODE}

Populasi dari penelitian ini adalah seluruh WUS usia 15-49 tahun yang menggunakan layanan internet di Pulau Lombok dan bersedia mengisi kuesioner melalui google form. Teknik sampling yang dipilih adalah accidental sampling dengan total 37 orang WUS. 
Penelitian ini merupakan penelitian deskriptif kuantitatif dengan rancangan penelitian cross sectional. Pengambilan data dilakukan dari tanggal 1 hingga 31 Mei tahun 2020 dengan menyebarkan pengumuman dan link google form melalui aplikasi social media dan WhatssApp. Uji statistiknya menggunakan Chi Square dengan $\alpha=0.05$. Instrumen yang digunakan adalah kuesioner yang dibuat menggunakan aplikasi google form.

\section{HASIL}

a. Karakteristik Responden Menurut Umur

Tabel 1. Karakteristik WUS berdasarkan umur Tahun 2020

\begin{tabular}{|c|l|c|c|}
\hline No. & \multicolumn{1}{|c|}{ Umur (Tahun) } & $\begin{array}{c}\text { Jumlah } \\
(\mathrm{n})\end{array}$ & $\begin{array}{c}\text { Persen } \\
(\%)\end{array}$ \\
\hline 1 & $<20$ tahun & 0 & 0 \\
\hline 2 & $20-35$ tahun & 22 & 59.5 \\
\hline 3 & $>35$ tahun & 15 & 40.5 \\
\hline & Total & 37 & 100 \\
\hline
\end{tabular}

Sumber : Data primer

Tabel 1 menunjukkan bahwa sebagian besar WUS berumur 20-35 tahun (59.5\%), hal ini dapat dikatakan usia tersebut sudah tepat untuk menikah karena merupakan usia reproduksi sehat. Responden yang berumur $>35$ tahun (40.5\%) telah masuk kedalam prioritas program deteksi dini, sehingga diharapkan telah melakukan pemeriksaan IVA minimal 1 kali (Kemenkes RI, 2015).

\section{b. Karakteristik Responden Menurut Umur Pertama Kali Menikah}

Tabel 2. Karakteristik WUS berdasarkan umur menikah pertama kali Tahun 2020

\begin{tabular}{|c|l|c|c|}
\hline No. & \multicolumn{1}{|c|}{ Umur (Tahun) } & $\begin{array}{c}\text { Jumlah } \\
(\mathrm{n})\end{array}$ & $\begin{array}{c}\text { Persen } \\
(\%)\end{array}$ \\
\hline 1 & $<20$ tahun & 6 & 16.2 \\
\hline 2 & $20-35$ tahun & 30 & 81.1 \\
\hline 3 & $>35$ tahun & 1 & 2.7 \\
\hline & Total & 37 & 100 \\
\hline
\end{tabular}

Sumber : Data primer
Tabel 2 menunjukkan usia responden pertama kali menikah sebagian besar responden menikah pada umur 20-35 tahun $(81,1 \%)$, sehingga dapat dikatakan bahwa responden menikah pada usia yang sudah aman karena merupakan reproduksi sehat, dimana organ reproduksi telah matang sehingga minim resiko jika selanjutnya akan hamil, melahirkan maupun menggunakan alat kontrasepsi. Namun, masih ada responden yang menikah pada usia $<20$ tahun $(16,2 \%)$ $\%$ ), dimana menikah pada usia ini akan akan meningkatkan resikoterkena kanker serviks 2 kali lebih besar bahkan meningkat 3-6 kali lebih besar pada WUS yang menikah pada usia <16 tahun (Kemenkes RI, 2016).

\section{c. Karakteristik Responden Menurut Tingkat Pendidikan}

Tabel 3. Karakteristik WUS berdasarkan Tingkat Pendidikan Tahun 2020

\begin{tabular}{|c|l|c|c|}
\hline No. & \multicolumn{1}{|c|}{ Umur (Tahun) } & $\begin{array}{c}\text { Jumlah } \\
(\mathrm{n})\end{array}$ & $\begin{array}{c}\text { Persen } \\
(\%)\end{array}$ \\
\hline 1 & Tidak sekolah & 1 & 2.7 \\
\hline 2 & Pendidikan dasar & 8 & 21.6 \\
\hline 3 & $\begin{array}{l}\text { Pendidikan } \\
\text { menengah }\end{array}$ & 7 & 18.9 \\
\hline 4 & Pendidikan tinggi & 21 & 56.8 \\
\hline & Total & 37 & 100 \\
\hline
\end{tabular}

Sumber : Data primer

Tabel 3 menunjukkan bahwa sebagian besar responden berpendidikan tinggi (56.8\%), dan paling sedikit tidak tamat sekolah dasar $(2.7 \%)$. Artinya, responden memiliki peluang yang besar untuk mendapatkan informasi kesehatan. Menurut Sedyaningsih (2010) pendidikan dan kesehatan saling berkaitan karena dengan pendidikan akan meningkatkan kemampuan hidup sehat seseorang.

d. Karakteristik Responden Menurut Wilayah Tempat Tinggal 
Tabel 4. Karakteristik WUS berdasarkan Wilayah Tempat Tinggal Tahun 2020

\begin{tabular}{|l|l|c|c|}
\hline No. & Umur (Tahun) & $\begin{array}{c}\text { Jumlah } \\
(\mathrm{n})\end{array}$ & $\begin{array}{c}\text { Persen } \\
(\%)\end{array}$ \\
\hline 1 & Pedesaan & 27 & 73 \\
\hline 2 & Perkotaan & 10 & 27 \\
\hline & Total & 37 & 100 \\
\hline
\end{tabular}

Sumber : Data primer

Tabel 4 memperlihatkan sebaran wilayah tempat tinggal responden yang sebagian besar di wilayah pedesaan $(73 \%)$. Wilayah tempat tinggal akan mempengaruhi dari segi akses terhadap informasi serta sarana dan prasarana. Untuk informasi telah banyak di diberikan pemerintah melalui upaya promosi dengan melibatkan tokoh agama dan tokoh masyarakat, serta melalui media cetak dan elektronik nasional maupun daerah.

\section{e. Perilaku periksa IVA Responden} Perilaku periksa IVA merupakan status pemeriksaan IVA resonden yang dapat dilihat pada tabel di bawah ini:

Tabel 5. Distribusi Responden berdasarkan Status Periksa IVA WUS Tahun 2020

\begin{tabular}{|c|l|c|c|}
\hline No. & $\begin{array}{c}\text { Perilaku periksa } \\
\text { IVA }\end{array}$ & Jumlah (n) & $\begin{array}{c}\text { Persen } \\
(\%)\end{array}$ \\
\hline 1 & Ya & 3 & 8.1 \\
\hline 2 & Tidak & 34 & 91.9 \\
\hline & Total & 37 & 100 \\
\hline
\end{tabular}

Sumber : Data primer

Dari tabel 5 didapatkan fakta bahwa sebagian besar WUS (91.9\%) tidak pernah periksa IVA, hanya sebagian kecil $(8.1 \%)$ responden yang periksa IVA. Hal ini sangat beresiko jika ada WUS yang mengidap kanker serviks dan tidak tidak dilakukan skrining, maka kemungkinan dilakukan pengobatan pada stadium awal akan kecil, karena kanker serviks tidak umumnya menunjukkan gejala setelah stadium lanjut. Menurut
Sinaga dan Limbong (2019) deteksi dini pada tahap pra klinis memungkinkan dilakukan pengobatan segera sehingga bisa memberikan prognosis terhadap penyakit, dimana hasilnya akan lebih baik daripada dilakukan ketika sudah parah atau terlambat.

\section{f. Tingkat Pengetahuan}

Tingkat pengetahuan responden tentang pemeriksaan IVA dapat dilihat pada tabel dibawah ini :

Tabel 6. Distribusi Responden berdasarkan Pengetahuan

\begin{tabular}{|c|l|c|c|}
\hline No. & $\begin{array}{c}\text { Perilaku periksa } \\
\text { IVA }\end{array}$ & $\begin{array}{c}\text { Jumlah } \\
(\mathrm{n})\end{array}$ & $\begin{array}{c}\text { Persen } \\
(\%)\end{array}$ \\
\hline 1 & Baik & 17 & 45.9 \\
\hline 2 & Cukup & 13 & 35.1 \\
\hline 3 & Kurang & 7 & 18.9 \\
\hline & Total & 37 & 100 \\
\hline
\end{tabular}

Sumber : Data primer

Dari tabel 6 terlihat bahwa sebagian besar responden memiliki pengetahuan yang baik (45.9\%), namun masih banyak responden yang memiliki pengetahuan yang kurang (18.9\%). Tingginya angka kematian akibat kanker serviks disebabkan karena terlambatnya diagnosis dimana 70\% kasus kanker serviks ditemukan pada stadium lanjut. Hal ini disebabkan oleh rendahnya pengetahuan masyarakat terkait kanker, seperti pengetahuan tentang tanda-tanda kanker serviks (Kemenkes, 2019). Penelitian Meliasari (2014) menemukan bahawa terdapat hubungan antara dukungan suami $(\mathrm{p}=0,00)$ dan pengetahuan $(\mathrm{p}=0,00)$ dengan perilaku periksa IVA PUS, dimana semakin tinggi. Adanya pemahaman yang baik tentang manfaat dan bahaya kanker serviks menjadikan masyarakat secara sadar memeriksakan diri. 


\section{g. Dukungan Suami}

Dukungan suami responden tentang pemeriksaan IVA dapat dilihat pada tabel dibawah ini :

Tabel 7. Distribusi Responden berdasarkan Dukungan Suami

\begin{tabular}{|c|l|c|c|}
\hline No. & \multicolumn{1}{|c|}{$\begin{array}{c}\text { Perilaku periksa } \\
\text { IVA }\end{array}$} & $\begin{array}{c}\text { Jumlah } \\
(\mathrm{n})\end{array}$ & $\begin{array}{c}\text { Persen } \\
(\%)\end{array}$ \\
\hline 1 & Baik & 27 & 73.0 \\
\hline 2 & Kurang & 10 & 27.0 \\
\hline & Total & 37 & 100 \\
\hline
\end{tabular}

Sumber : Data primer

Dari tabel 7 terlihat bahwa sebagian besar responden memiliki dukungan suami yang baik $(73.9 \%)$, namun masih banyak responden yang memiliki dukungan suami yang kurang (27.0\%). Suami memiliki peran penting dalam menjaga kesehatan reproduksi pasangan, keterlibatan dan dukungan suami akan semakin memudahkan wanita dalam memenuhi hak-hak reproduksinya. Penelitian Wildayanti (2017) menunjukkan bahwa terdapat hubungan antara dukungan suami (0.031) dengan keikutsertaan pemeriksaan IVA pada PUS. Dukungan suami dapat berupa pemberian informasi, penyediaan biaya hingga dukungan spiritual.

\section{h. Hubungan Pengetahuan dengan Perilaku Periksa IVA WUS}

Hubungan Pengetahuan dengan perilaku periksa IVA responden dapat dilihat pada tabel dibawah ini :

Tabel 8. Tabulasi Hubungan Pengetahuan dengan Perilaku Periksa IVA WUS

\begin{tabular}{|c|c|c|c|c|c|}
\hline & \multicolumn{4}{|c|}{ Perilaku periksa IVA } & \multirow{3}{*}{$\begin{array}{c}P- \\
\text { value }\end{array}$} \\
\hline & \multicolumn{2}{|c|}{$\mathrm{Ya}$} & \multicolumn{2}{|c|}{ Tidak } & \\
\hline & $\mathrm{n}$ & $\%$ & $\mathrm{n}$ & $\%$ & \\
\hline Pengetahuan & & & & & \\
\hline Baik & 1 & 33.3 & 16 & 47.1 & \\
\hline Sedang & 1 & 33.3 & 12 & 35.3 & 0.789 \\
\hline Kurang & 1 & 33.3 & 6 & 17.6 & \\
\hline Dukungan Suami & & & & & \\
\hline Baik & 3 & 100 & 24 & 70.6 & 0.272 \\
\hline Kurang & 0 & 0 & 10 & 29.4 & \\
\hline
\end{tabular}

Sumber : Data primer
Dari table 8 terlihat bahwa Responden yang melakukan periksa IVA memiliki pengetahuan baik (33,3\%), sedang (33,3\%), dan kurang $(33,3 \%)$. Hasil analisis uji Chi Square antara pengetahuan dengan perilaku periksa IVA ibu didapat nilai $\mathrm{p}=$ 0.789, hal ini menunjukkan bahwa tidak ada hubungan antara pengetahuan dengan perilaku periksa IVA. Untuk Dukungan suami didapatkan hasil WUS yang periksa IVA memiliki dukungan suami yang baik (100\%). Hasil analisis uji Chi Square antara dukungan suami dengan perilaku periksa IVA ibu didapatkan nilai $\mathrm{p}=0,272$, hal ini menunjukkan bahwa tidak ada hubungan antara pengetahuan dengan perilaku periksa IVA.

Pengetahuan berkaitan dengan motivasi sesorang untuk berperilaku kesehatan yang baik. Namun, pada kenyataannya pengetahuan saja tidak cukup untuk mengubah perilaku seseorang untuk hidup sehat, pengetahuan harus masuk kedalam diri seseorang sehingga mempengaruhi sikapnya terhadap kesehatan (Emilia, Prabandari dan Supriyati, 2019). Dari hasil penelitian terlihat bahwa WUS yang memiliki pengetahuan baik hanya $33.3 \%$ yang melakukan periksa IVA. Begitu juga dengan WUS yang memiliki pengetahuan sedang, tetapi WUS yang berpengetahuan rendah juga ada yang melakukan periksa IVA. Hal ini membuktikan bahwa pengetahuan yang baik tidak menjamin seseorang akan berperilaku sehat. Hasil penelitian ini sejalan dengan penelitian yang dilakukan oleh Lestari dan Syaifudin (2016) dengan nilai Pvalue $=0,142$ tidak menemukan adanya hubungan antara pengetahuan dengan perilaku periksa IVA WUS.

Dukungan suami erat kaitannya dengan dengan patron paternalistic 
yang masih terasa disebagian besar masyarakat, hal ini menjadikan keputusan suami akan sangat dihormati. Suami yang mendukung pasangannya untuk melakukan deteksi dini kanker leher rahim akan lebih membantu tugas dari petugas kesehatan dan pemerintah (Kemenkes RI, 2015). Namun, dari hasil penelitian terlihat bahwa dari 17 orang WUS yang mendapatkan dukungan suami yang baik, hanya 1 orang $(5,9 \%)$ yang melakukan periksa IVA. Artinya, dukungan dari suami tidak selalu mendorong WUS untuk melakukan pemeriksaan IVA.

Ada beberapa faktor yang menjadi kendala WUS untuk periksa IVA selain dari kurangannya pengetahuan dan dukungan suami, diantaranya adalah kurangnya fasilitas pelayanan kesehatan yang melayani IVA dan faktor dari masyarakat sendiri yang masih banyak merasa malu, perasaan takut dan malas, sibuk bekerja, hanya ingin ditangani oleh dokter perempuan, hingga masalah finansial (Sumanadi, 2015). Berdasarkan hasil analisis kuesioner pengetahuan, pertanyaan yang paling banyak salah dijawab oleh responden adalah pertanyaan mengenai tempat dan siapa yang dapat memberikan pelayanan IVA, banyak WUS yang menjawab bahwa periksa IVA hanya dilakukan di rumah sakit (59.5\%) dan periksa IVA hanya dapat diberikan oleh dokter spesialis kandungan (64.9\%). Hal ini akan menghambat WUS untuk melakukan periksa IVA karena dokter spesialis dan rumah sakit biasanya jauh dari pedesaan, sehingga tidak memanfaatkan fasilitas kesehatan lain seperti puskesmas dan Bidan desa.

\section{KESIMPULAN}

Tidak ada hubungan motivasi dan dukungan suami terhadap perilaku periksa IVA WUS. 


\section{DAFTAR PUSTAKA}

Agustini, Aat. 2019. Promosi Kesehatan. Yogyakarta : Deepublish

Kemenkes RI. 2015. Tabloid Mediakom. Kanker Pembunuh Papan Atas. https://www.kemkes.go.id/develop ment/resources/download/tabloid/ mediakom/mediakom-kankerpembunuh-papan-atas.pdf. Sitasi 01 Juni 2020.

Kemenkes RI. 2015. Program Nasional Gerakan Pencegahan Dan Deteksi Dini Kanker Kanker Leher Rahim Dan Kanker Payudara 21 April. http://p2ptm.kemkes.go.id/uploads /2016/10/Panduan-ProgramNasional-Gerakan-Pencegahandan-Deteksi-Dini-Kanker-KankerLeher-Rahim-dan-Kanker-

Payudara-21-April-2015.pdf. Sitasi 01 Juni 2020

Kemenkes RI, 2016. Siapa Rentan Kanker Leher Rahim? http://p2ptm.kemkes.go.id/artikelsehat/siapa-rentan-kanker-leherrahim.

Kemenkes RI. 2018. Profil Kesehatan Indonesia 2018. https://pusdatin.kemkes.go.id/reso urces/download/pusdatin/profilkesehatanindonesia/PROFIL KESEHATAN 2018 1.pdf. Sitasi 01 Juni 2020

Kemenkes RI. 2019. Cerdik Tanggulangi Kanker. https://www.kemkes.go.id/article/v iew/19082000006/cerdiktanggulangi-kanker.html. Sitasi 01 Juni 2020

Kemenkes RI. 2019. Hari Kanker Sedunia 2019. https://www.kemkes.go.id/article/v iew/19020100003/hari-kankersedunia-2019.html. Sitasi 01 Juni 2020

Lestari, M.A., dan Syaifudin. 2016. Hubungan Pengetahuan Dan Sikap Wus Dengan Perilaku
Melakukan Pemeriksaan IVA Di Kelurahan Kotabaru Wilayah Kerja Puskesmasgondokusumanii Yogyakarta. Sitasi 01 Juni 2020. http://digilib.unisayogya.ac.id/202 7/1/NASKAH\%20PUBLIKASI\%2 0TERBARU\%20FIX.pdf

Meliasari, Dewi. 2014. Pengetahuan Dan Dukungan Suami Berhubungan Dengan Tindakan Pemeriksaan Iva Pada Pasangan Usia Subur (PUS)Di Desa Sunggal Kanan Tahun 2014. Sitasi 01 Juni 2020.

$\mathrm{Di}$

http://eprints.poltekkesjogja.ac.id/1 732/1/SKRIPSI.pdf

Pakkan, Rosmiati. 2017. Faktor-Faktor Yang Berhubungan Dengan Motivasi Ibu Melakukan Pemeriksaan Metode Inspeksi Visual Asam Asetat (IVA) Di Kelurahan Lepo-Lepo Kota Kendari. Sitasi 01 Juni 2020 di http://ibi.or.id/journal/index.php/ji b/article/download/20/18/

Sedyaningsih, Endang R. 2010. Pendidikan Dan Kesehatan Menentukan Kualitas Sumber Daya Manusia. https://www.kemkes.go.id/develop ment/site/jkn/index.php?cid=1179 \&id=pendidikan-dan-kesehatanmenentukan-kualitas-sumber-dayamanusia.html. . Sitasi 01 Juni 2020

Sinaga, M., dan Limbong, D. 2019. Dasar Epidemiologi. Yogyakarta : Deepublish

Sudrajad, sally. 2017. Harpa Sebagai Harapan di Indonesia. Buletin Harpa.

http://yayasankankerindonesia.org/ storage/article/2cfbac39cedaa4426 a9b4d1ce1ba2891.pdf

Sumanadi. 2015. Deteksi Dini Cegah Kanker Serviks. Tabloid Mediakom. Kanker Pembunuh Papan Atas. https://www.kemkes.go.id/develop ment/resources/download/tabloid/ 
mediakom/mediakom-kanker-

pembunuh-papan-atas.pdf. Sitasi 01 Juni 2020

Wildayanti. 2017. Hubungan Dukungan

Suami Dengan Keikutsertaan

Pemeriksaan Inspeksi Visual Asam

Asetat (Iva) Pada Pus Di

Puskesmas Kotagede 2 Kota

Yogyakarta. Sitasi 01 Juni 2020 di

http://digilib.unisayogya.ac.id/447

1/2/Baru\%20Naskah\%20Publikasi

\%20Wildayanti\%20\%2817101043

34\%29\%20barux\%20-

\%20Copy.pdf 